\title{
Maternofetal Transfer of IgG Anti-Escherichia coli Antibodies with Enhanced Avidity and Opsonic Activity in Very Premature Neonates
}

\author{
F. H. SENNHAUSER, A. BALLOCH, R. A. MACDONALD, M. J. SHELTON, AND D. M. ROBERTON \\ Department of Immunology [F.H.S., A.B., R.A.M., M.J.S., D.M.R.] and Department of Paediatrics [F.H.S., \\ D.M.R.], University of Melbourne, Royal Children's Hospital, Melbourne, Australia
}

\begin{abstract}
Total IgG concentrations, IgG antibody concentrations to pooled Escherichia coli antigens, and IgG anti-E. coli antibody avidity were measured in cord and maternal serum samples collected from 52 mother-infant pairs after premature delivery (mean gestational age 28 wk, range $23-33 \mathrm{wk})$. The mean IgG anti-E. coli antibody concentration in cord serum $(1.86$ relative units $/ \mathrm{mL})$ was markedly lower than in maternal serum $(5.42$ relative units $/ \mathrm{mL})$ at this gestation $(p<0.0001)$. Cord serum IgG anti-E. coli antibody concentrations correlated closely with maternal IgG anti- $E$. coli concentrations when controlled for the effect of gestational age (partial correlation coefficient $0.89 ; p<0.001$ ) but only weakly with gestational age when controlled for maternal IgG antibody concentrations (partial correlation coefficient $0.23 ; p=0.06$ ). The mean ratio of cord to maternal IgG anti- $E$. coli antibody concentrations was considerably lower than the mean ratio for total IgG concentrations $(0.34$ versus $0.72 ; p<0.001)$. The mean avidity of IgG antibody for the pooled $E$. coli antigens was significantly greater in cord serum than in maternal serum $(2.45$ versus $1.99 \mathrm{M} ; p<0.0001)$. There was a close correlation between cord and maternal antibody avidity $(r$ $=0.70 ; p<0.001$ ), but cord IgG antibody avidity did not correlate with gestational age $(r=-0.07 ; p=0.61)$, nor with cord IgG anti- $E$. coli antibody concentrations $(r=$ $0.10 ; p=0.50$ ). Heat stable serum opsonic activity for the pooled $E$. coli antigens per unit of IgG antibody, measured by augmentation of normal neutrophil iodination responses, was 2 -fold greater in cord serum than maternal serum for the 20 serum pairs tested. Heat stable opsonic activity per unit of IgG antibody correlated closely with IgG antibody avidity in cord and maternal sera $(r=0.96$ and 0.94 , respectively). These findings suggest that there is selective transplacental transport of high avidity antibody with enhanced opsonic activity for these antigens early in the 3rd trimester of pregnancy. (Pediatr Res 27: 365-371, 1990)
\end{abstract}

\section{Abbreviations}

EIA, enzyme immunoassay

NICU, neonatal intensive care unit

PBS-T, PBS-Tween

PBS-T/SMP, 2.5\% skim milk powder in PBS-T

NIMM, neutrophil iodination micro-method

\footnotetext{
Received July 11, 1988; accepted November 30, 1989.

Correspondence: Prof. Don M. Roberton, M.D., FRACP, Department of Paediatrics, Adelaide Childrens Hospital, North Adelaide. South Australia. 5006 Australia.

F.H.S. was supported by Grants 83.337.0.86 from the Swiss National Research Foundation and a grant from the Swiss Academy of Medical Sciences. R.A.M. was supported by grants from the Royal Children's Hospital Research Foundation.
}

Transplacental transfer of maternal IgG antibody provides passively acquired systemic immunity in the neonatal period and early infancy (1), with the greater proportion of placental $\mathrm{IgG}$ transport occurring during the last trimester of pregnancy (2-6). Low concentrations of transplacentally acquired specific antibody in very premature infants, in conjunction with other microbial and host factors, may contribute to the observed susceptibility of these infants to infection (1, 3, 7-11).

The relationship of neonatal serum IgG concentrations and gestational age has been described by several investigators $(1,2$, $4,9,12)$, as has the relationship of IgG subclass transplacental transfer and gestational age $(9,11,13)$. However, there are relatively few studies of specific antibody transfer in prematurity $(2,7,8,14,15)$, and little is known of the functional capacity of maternally derived antibody in the neonate. Sato et al. (14) showed that cord sera from term infants had higher concentrations of neutralizing antibodies to measles, mumps, and rubella than did paired maternal sera. The mean ratio of cord blood to maternal neutralizing antibody was greater for measles than for mumps or rubella, suggesting differential transport of functional antibody. Chudwin et al. (8) found low concentrations of antibody against type $7 \mathrm{~F}$ pneumococcal polysaccharide and low opsonic activity to this antigen in cord sera from preterm and term neonates in comparison with paired maternal sera, although the mean cord serum total IgG concentrations were greater than maternal $\operatorname{lgG}$ concentrations.

In a recent study (16), IgG-dependent opsonic activity for coagulase negative staphylococci was found to be significantly lower in serum collected from premature neonates during the first $2 \mathrm{wk}$ of life than in paired maternal serum samples. These findings were similar to those reported previously by Fleer $e t$ al. (15), and the authors suggested either that there may be preferential transport of some IgG antibodies across the placenta, or that the function of some IgG antibodies may be impaired by placental transport.

Antibody avidity is an important determinant of antibody efficacy (17-19). To further investigate the functional characteristics of transplacentally acquired IgG antibody in premature neonates, we measured total IgG concentrations, concentrations of IgG antibody to a pooled Escherichia coli antigen preparation, and the avidity of IgG anti-E.coli antibody in paired cord and maternal serum samples from 52 neonates delivered between 23 and $33 \mathrm{wk}$ gestation (mean $28 \mathrm{wk}$ ). The opsonic activity of antiE.coli antibody was determined in 20 paired cord and maternal sera and the relationship of opsonic activity and antibody avidity was assessed.

\section{MATERIALS AND METHODS}

Serum samples. Fifty-two infants born at the Royal Women's Hospital, Melbourne, and the Monash Medical Center, Melbourne, or neonates who were transferred within the first $24 \mathrm{~h}$ of life to the NICU of the Royal Children's Hospital, Melbourne, 
were enrolled in the study. Informed written parental consent was obtained in accordance with the guidelines of The Declaration of Helsinki.

All infants enrolled were premature neonates; the mean gestational age was $28 \mathrm{wk}$ (range 23-33 wk; 48 were of $30 \mathrm{wk}$ gestation or less). Gestational age was assessed by serial ultrasonography and by examination of the newborns. None of the infants had any clinical evidence of intrauterine infection.

Venous blood was collected from all 52 mothers within $48 \mathrm{~h}$ of delivery. Cord blood from their respective infants was collected by careful venepuncture of the umbilical vein immediately after delivery of the placenta. Samples were refrigerated at $+4^{\circ} \mathrm{C}$, and sera were separated with $24 \mathrm{~h}$ of collection. The sera were frozen immediately after separation and were stored at $-70^{\circ} \mathrm{C}$ in polypropylene containers until assayed.

Quantitation of total serum $\operatorname{IgG}$, IgA, and IgM concentrations. EIA for the measurement of total IgG, IgA, and IgM concentrations in maternal and cord sera were performed as described previously (20). All samples were tested in duplicate at four different dilutions. A pooled human serum reference preparation (21) containing $100 \mathrm{IU}$ of $\mathrm{IgG} / \mathrm{mL}(=806.4 \mathrm{mg} / \mathrm{dL}), 102 \mathrm{IU}$ of $\mathrm{IgA} / \mathrm{mL}(=144.9 \mathrm{mg} / \mathrm{dL})$, and $114 \mathrm{IU}$ of $\mathrm{IgM} / \mathrm{mL}(=96.6 \mathrm{mg} /$ dL) was tested at 10 -fold dilutions ranging from $1 / 10^{3}$ to $1 / 10^{8}$ on each plate. The lower limits of sensitivity of the EIA for IgG, $\mathrm{IgA}$, and $\mathrm{IgM}$ were $0.1525 \times 10^{-4} \mathrm{IU} / \mathrm{mL}(1.23 \mathrm{ng} / \mathrm{mL}), 0.3097$ $\times 10^{-4} \mathrm{IU} / \mathrm{mL}(0.44 \mathrm{ng} / \mathrm{mL})$, and $1.1801 \times 10^{-4} \mathrm{IU} / \mathrm{mL}(0.29$ $\mathrm{ng} / \mathrm{mL}$ ), respectively.

Antibody to pooled E. coli antigens. Enzyme immunoassays were used to measure specific $\operatorname{IgG}, \operatorname{IgA}$, and $\operatorname{IgM}$ antibody to E.coli antigens in all serum samples. A pool of E.coli antigens representing the eight E.coli strains found most frequently in faecal isolates and/or disease states (serotypes O1, O2, O4, O6, O7, O16, O18, O75) was prepared by heat extraction $(22,23)$. Organisms were subcultured from nutrient agar slopes into ToddHewitt broths and were incubated anaerobically for $15 \mathrm{~h}$. The cultures were then pooled and centrifuged, and the pellets were resuspended in PBS-T. The suspension was boiled in a water bath for $60 \mathrm{~min}$ and then was centrifuged and the supernatant retained. Aliquots of supernatant were stored in glass at $-70^{\circ} \mathrm{C}$ until use. The protein and nucleic acid concentrations of this stock antigen preparation were 0.49 and $0.032 \mathrm{mg} / \mathrm{mL}$, respectively (24). Lipopolysaccharide content was estimated by using the limulus amebocyte lysate test (Pyrogent, Whittaker M. A. Bioproducts, Walkersville, MD) (25), with the FDA Reference Standard Endotoxin as a reference. The stock E.coli antigen contained $8.0^{*} 10^{4}$ endotoxin units $/ \mathrm{mL}$.

Ninety-six-well microtiter plates (NUNC, Kamstrup, Denmark) were incubated with $100 \mathrm{uL}$ of a $1 / 800$ dilution of the stock E.coli antigen preparation in $0.05 \mathrm{M}$ bicarbonate buffer $\left(\mathrm{pH} 9.5\right.$ ) in each test well for $2 \mathrm{~h}$ at $37^{\circ} \mathrm{C}$ and then overnight at $+4^{\circ} \mathrm{C}$. After washing, $50 \mu \mathrm{L} /$ well of serum diluted in PBS-T/ SMP ( $\mathrm{pH} 7.2$ ) was added and incubated for $2 \mathrm{~h}$ at $37^{\circ} \mathrm{C}$. The addition of SMP was used to improve protein binding (26). After washing, $50 \mu \mathrm{L}$ of a $1 / 1000$ dilution of peroxidase conjugated, affinity isolated goat antihuman $\operatorname{IgG}$ or $\operatorname{IgA}$ or IgM (Tago, Burlingame, CA) in PBS-T/SMP was added and incubated for 2 $h$ at $37^{\circ} \mathrm{C}$. The plates were then washed and $50 \mu \mathrm{L}$ of orthophenylene diamine substrate was added for $15 \mathrm{~min}$. The reaction was stopped by adding $25 \mu \mathrm{L}$ of $8 \mathrm{~N} \mathrm{H}_{2} \mathrm{SO}_{4}$ to each well. Absorbance values were read at $492 \mathrm{~nm}$ using a Titertek Multiscan (Flow Laboratories, McLean, VA).

All samples were tested in duplicate and at four dilutions ranging from $1 / 10$ to $1 / 1250$ for cord sera and from $1 / 50$ to $1 / 6250$ for maternal sera, respectively. Mother-infant pairs of sera were tested in adjacent rows on the same microtiter plates. The pooled human reference serum (21) was included in serial dilutions on each test plate. This reference serum was assigned an arbitrary value of 10 relative units $/ \mathrm{mL}$ of anti-E.coli $\mathrm{IgG}$, IgA, and IgM antibody, respectively. Each test sample was quantitated by reading from the linear portion of the reference serum standard curve using a computer generated spline function curve fitting program. The standard curve was derived from values for sequential 5 -fold dilutions from $1 / 10$ to $1 / 31250$. Values were expressed in relative units/mL of serum.

Specificity of the assay for $\operatorname{IgG}$ (and $\operatorname{IgA}$ or $\operatorname{IgM}$ ) antibody to E.coli antigen was demonstrated by appropriate liquid phase adsorption experiments using the reference serum and the pooled E.coli antigen preparation. The lower limit of detection was taken at OD values $>$ three times background (sample free) OD readings.

Avidity of $\operatorname{Ig} G$ antibody for pooled E.coli antigens. The avidity of IgG antibody for the pooled E.coli antigens was estimated by using a modified EIA incorporating thiocyanate elution as described previously $(19,27)$. Preliminary experiments were performed to ensure that no elution of solid phase bound E.coli antigen occurred at any of the molarities of thiocyanate used in subsequent assays and the assays were performed in antigen excess for all isotypes. Under these conditions, the avidity of IgG antibody is unchanged when whole serum is compared with serum depleted of IgA and IgM by immunoadsorption (28).

Ninety-six-well microtiter plates were coated with the same E.coli antigen as described above. After four washes with PBS$\mathrm{T}, 50 \mu \mathrm{L}$ of serum sample in PBS-T/SMP was incubated in series of duplicate wells for $2 \mathrm{~h}$ at $37^{\circ} \mathrm{C}$. For each sample a dilution was used at which, in preliminary experiments, antigen excess had been demonstrated for each Ig isotype and at which further dilution of the sample did not affect the estimation of the avidity index.

After washing with PBS-T, bound antibody was eluted by adding $100 \mu \mathrm{L}$ ammonium thiocyanate $\left(\mathrm{NH}_{4} \mathrm{SCN}\right)$ in $0.1 \mathrm{M}$ phosphate buffer ( $\mathrm{pH}$ 6.0) to the appropriate wells in duplicate, in concentrations ranging from 1.0 to $4.0 \mathrm{M}$. On each test plate, four replicate wells for each sample were incubated with phosphate buffer alone. Results for these wells represented $100 \%$ antibody binding. The plates were incubated for exactly $30 \mathrm{~min}$ at room temperature before washing three times with PBS-T and proceeding with the assay for residual IgG anti-E.coli antibody as described above. Sample-free background values were subtracted from each absorbance reading. The relative avidity index for each sample was defined as the molarity of thiocyanate required to reduce the absorbance (OD value) of the E.coli EIA by $50 \%$ and was derived from the elution curves as described previously $(19,27,29)$. The data for each sample were fitted to a graph of $\log _{10}$ (\% of initial absorbance) versus molarity of $\mathrm{NH}_{4} \mathrm{SCN}$ by third degree polynomial regression analysis, using a graph generation program (Grafit/1000, Corporate Computer Systems, NJ) on a Hewlett-Packard 1000 computer (HewlettPackard Co., Palo Alto, CA) (27).

Serum opsonic activity for pooled E.coli antigens. NIMM was used to measure opsonic activity by determining neutrophil incorporation of radiolabelled iodide in the presence of test serum samples in comparison with a pooled normal adult human serum standard as described previously $(30,31)$. Assays for opsonic activity were performed on the 20 cord and maternal paired serum samples for which sufficient sample was available.

In brief, polymorphonuclear leucocytes were isolated from peripheral blood from a healthy adult donor on a Ficol-Isopaque density gradient followed by dextran sedimentation (T500, Pharmacia Fine Chemicals, Piscataway, NJ, 6\% in Dulbecco's PBS). Neutrophils recovered were washed and resuspended in iodination buffer [137 mM NaCl, $2.6 \mathrm{mM} \mathrm{KCl}, 8.1 \mathrm{mM} \mathrm{Na}_{2} \mathrm{HPO}_{4}$, $1.5 \mathrm{mM} \mathrm{KH}_{2} \mathrm{PO}_{4}, 1.0 \mathrm{mM} \mathrm{MgCl} \cdot 6 \mathrm{H}_{2} \mathrm{O}$, and $1.0 \mathrm{mM} \mathrm{CaCl}_{2}$ (fused)] (31). Heat-killed E.coli antigen was prepared by heating the same pool of E.coli strains described above for $30 \mathrm{~min}$ at $80^{\circ} \mathrm{C}$, washing the organisms three times in PBS and resuspending in neutrophil iodination buffer to an OD of 1.6 at $540 \mathrm{~nm}$ (31). The protein and nucleic acid concentration of the antigen preparation were 0.39 and $0.042 \mathrm{mg} / \mathrm{mL}$, respectively. The antigen preparation contained $4.5^{*} 10^{5}$ endotoxin units $/ \mathrm{mL}$.

Assays were performed in duplicate in microtitre plates (Cooke 
Engineering, Edwardstown, South Australia), the reaction mixture consisting of $50 \mu \mathrm{L}$ of neutrophil suspension $\left(1 \times 10^{6} /\right.$ well $)$, $50 \mu \mathrm{L}$ iodination buffer containing $2.2 \mathrm{mM}$ D-glucose, $50 \mu \mathrm{L}$ of $80 \mu \mathrm{m} \mathrm{Nal}$ in iodination buffer to which was added $\mathrm{Na}^{125} \mathrm{I}$ to an activity of $4 \mu \mathrm{Ci} / \mathrm{mL}, 50 \mu \mathrm{L}$ of pooled heat killed E.coli antigen, and $25 \mu \mathrm{L}$ of a $1 / 4$ dilution of serum sample (final serum concentration $2.8 \%$ ). Paired cord and maternal sera were tested on the same plate. The plates were incubated for $60 \mathrm{~min}$ at $37^{\circ} \mathrm{C}$, and the cells harvested onto glass fiber filters using a Titertek Cell Harvester (Skatron, Norway) which were then washed and air dried for $10 \mathrm{~s}$. The glass fiber discs were placed in polystyrene tubes and the ${ }^{125} \mathrm{I}$ activity/min recorded on a gamma counter (Minaxi, Auto gamma 5000 series, Packard Instrument Co., Inc., Downers Grove, IL).

Serum-free controls were included in each assay to determine nonspecific incorporation of ${ }^{125} \mathrm{I}$, the mean value for which was subtracted from test values. Mean values were less than the $1 \%$ of results for serum containing wells. Pooled human adult serum from eight healthy donors that had been stored in glass at $-70^{\circ} \mathrm{C}$ after collection was used in each assay as a standard. Opsonic activity of test samples was determined using untreated serum (total opsonic activity) and serum heated to $56^{\circ} \mathrm{C}$ for $30 \mathrm{~min}$ (heat stable opsonic activity). Heat labile opsonic activity was derived from the difference between total and heat stable opsonic activity. Results for test samples were calculated as nmoles of iodine fixed per $10^{6}$ cells and were expressed as a percentage of the mean for the results for the untreated pooled adult serum standard to correct for differing polymorphonuclear leucocyte donor preparations as described previously (30). The mean results for the standard serum for the two polymorphonuclear leucocyte preparations used were 0.507 and $1.43 \mathrm{nmol}{ }^{125} \mathrm{I} / 10^{6}$ cells, respectively.

Specific heat stable opsonic activity and antibody avidity. Heat stable opsonic activity per relative unit of IgG anti-E.coli antibody (specific heat stable opsonic activity) was calculated for all test samples. Correlations were sought between specific heat stable opsonic activity and IgG antibody avidity per relative unit of IgG anti-E.coli antibody (specific IgG antibody avidity).

Quality control. The intra- and interassay coefficients of variation for each of the total Ig, E.coli antibody, and antibody avidity assays were calculated using the replicate values for the reference serum (32). The results ranged between 0.6 and $10.6 \%$.

Statistics for data analysis. Logarithmic transformations of all data were used to derive mean values and for statistical analyses. Comparative analyses of paired samples were performed using the paired $t$ test. Pearson correlation analyses were used to determine correlations for paired cord and maternal serum samples. Partial correlation coefficients were calculated to correct for the effect of gestational age, maternal IgG concentrations, or maternal $\mathrm{IgG}$ anti-E.coli antibody concentrations as appropriate when comparing maternal and cord values.

\section{RESULTS}

Total $\operatorname{Ig} G, \operatorname{IgA}$, and $\operatorname{Ig} M$ concentrations. All sera contained IgG. The mean IgG concentrations for cord and maternal sera are shown in Table 1 . The total IgG concentration was significantly higher for maternal sera than for paired cord sera $(p<$ $0.0001)$. Cord serum total IgG concentrations increased proportionately with gestational age (Fig. 1) and were significantly correlated with gestational age at delivery when controlled for maternal IgG concentrations (partial correlation coefficient 0.55 ; $p<0.001)$. However, cord serum total IgG concentrations in these neonates correlated only weakly with maternal total IgG concentrations, even when controlled for the effect of gestational age (partial correlation coefficient $0.20 ; p=0.08$ ).

The mean cord: maternal ratio for serum total IgG concentrations was 0.72 (Table 1). The cord: maternal ratio for total IgG concentrations increased with increasing gestation. There was a significant correlation between the cord:maternal ratio for $\mathrm{IgG}$ concentrations and gestational age $(r=0.48 ; p<0.001)$.
All sera had detectable IgA concentrations, with only very low levels of IgA being present in cord serum samples. The mean concentrations for total IgA in maternal and cord sera were 85.7 and $0.33 \mathrm{IU} / \mathrm{mL}$, respectively (range $27.0-322.0$ and $0.04-5.4$ $\mathrm{IU} / \mathrm{mL})(p<0.0001)$. The mean concentrations for total IgM in maternal and cord sera were 176 and $10.1 \mathrm{IU} / \mathrm{mL}$, respectively (range 63.0-490.0 and 3.6-68.9 IU/mL) $(p<0.0001)$. There was no significant correlation between maternal and cord IgA concentrations $(r=0.02)$ or $\operatorname{IgM}$ concentrations $(r=0.20)$. There was no correlation between gestational age and total IgA concentrations or total IgM concentrations in cord sera $(r=0.16 ; p=$ 0.27 and $r=0.12 ; p=0.41$, respectively).

Antibody to pooled E.coli antigens. All sera had detectable IgG antibody to the pooled E.coli antigens. The mean IgG anti-E.coli antibody concentrations for cord and maternal sera are shown in Table 1. As for total $\mathrm{IgG}$, the values for $\mathrm{IgG}$ anti-E.coli antibody concentrations were significantly higher for maternal sera than for paired cord serum samples $(p<0.0001)$.

The concentrations of $\mathrm{IgG}$ antibody to E.coli in cord sera correlated weakly with gestational age (Fig. $2 A$ ), the partial correlation coefficient after controlling for maternal $\mathrm{IgG}$ antibody concentration being $0.23(p=0.06)$. Cord and maternal IgG anti-E.coli antibody concentrations correlated closely when controlled for gestation (partial correlation coefficient $0.89 ; p<$ 0.001 ). Cord: maternal IgG anti-E.coli antibody ratios increased with increasing gestation (Fig. $2 B ; r=0.42 ; p<0.001$ ).

Only 24 of the 52 cord sera from premature neonates had detectable IgA antibodies to the E.coli antigens. Values were very low, the maximum concentration of IgA anti-E.coli antibody detected being 0.6 relative units $/ \mathrm{mL}$.

IgM antibody to E.coli was detected in 48 of the 52 cord sera, the maximum concentration being 1.9 relative units $/ \mathrm{mL}$. Cord serum $\operatorname{IgA}$ and $\operatorname{IgM}$ anti-E.coli antibody concentrations correlated poorly with gestational age at delivery $(r=0.002 ; p=0.99$ and $r=0.24 ; p=0.11$, respectively).

$\operatorname{IgA}$ and IgM anti-E.coli antibodies were detected in all maternal sera. The mean IgA and IgM antibody concentrations were 9.9 relative units/mL (range $1.7-142.0$ ) and 18.7 relative units/ $\mathrm{mL}$ (range 2.2-134.0), respectively. There were no significant correlations between cord and maternal IgA or IgM anti-E.coli antibody concentrations $(r \leq 0.22)$.

Comparison of cord:maternal ratios for $1 g G$ anti-E.coli antibody concentrations and total IgG concentrations. The mean cord:maternal ratio for IgG anti-E.coli antibody was markedly lower than the mean cord: maternal ratio for total IgG concentrations $(0.34$ versus $0.72 ; p<0.001)$

Avidity of $\mathrm{Ig} G$ antibody for pooled E.coli antigens. The mean avidity index for IgG anti-E.coli antibody in cord sera was 2.45 $M$. This value was significantly greater than the mean avidity index of $1.99 \mathrm{M}$ for paired maternal sera $(p<0.0001)$ (Table 1$)$. The mean cord:maternal ratio for $\operatorname{IgG}$ antibody avidity was 1.23. There was a significant correlation between the avidity indices of paired cord and maternal serum samples $(r=0.70 ; p$ $<0.001)$. However, there was no correlation between the avidity indices in cord sera and gestational age at premature delivery $(r$ $=-0.07 ; p=0.61$ ). There was no correlation between the avidity indices of IgG anti-E.coli antibody and total IgG concentrations or IgG anti-E.coli concentrations in cord or maternal serum samples (all $r<0.13$ ).

Serum opsonic activity for pooled E.coli antigens. The results for total IgG concentrations, IgG anti-E.coli antibody concentrations, and $\operatorname{IgG}$ antibody avidity indices for the 20 paired cord and maternal serum samples on whom assays of opsonic activity were performed are shown in Table 2 . The mean gestational age of these 20 neonates was 28.5 wk (range 26-31 wk).

The mean total opsonic activity for the pooled E.coli antigens was greater in maternal samples than in paired cord serum samples (cord-maternal ratio 0.44) (Table 3). However, the difference between cord and maternal samples was less after heating at $56^{\circ} \mathrm{C}$ for $30 \mathrm{~min}$ (cord-maternal ratio 0.84 ). Heat labile opsonic 
Table 1. Mean total IgG concentrations, IgG anti-E. coli antibody concentrations and avidity indices for IgG anti-E. coli antibody

\begin{tabular}{|c|c|c|c|}
\hline & $\begin{array}{l}\text { Total IgG } \\
(\mathrm{IU} / \mathrm{mL})\end{array}$ & $\begin{array}{l}\text { IgG anti- } E \text {. coli antibody } \\
\text { (relative units/mL) }\end{array}$ & $\begin{array}{l}\text { IgG antibody avidity index } \\
\left(\mathrm{M} \mathrm{NH}_{4} \mathrm{SCN}\right)\end{array}$ \\
\hline $\begin{array}{l}\text { Cord serum } \\
\quad(\text { mean, range })\end{array}$ & $\begin{array}{l}60.6 \\
(22.6-136.0)\end{array}$ & $\begin{array}{l}1.86 \\
(0.21-14.80)\end{array}$ & $\begin{array}{l}2.45 \\
(1.39-3.86)\end{array}$ \\
\hline $\begin{array}{r}\text { Maternal serum } \\
\text { (mean, range) }\end{array}$ & $\begin{array}{l}83.9 \\
(32.2-241.0)\end{array}$ & $\begin{array}{l}5.42 \\
(0.69-49.20)\end{array}$ & $\begin{array}{l}1.99 \\
(0.98-3.29)\end{array}$ \\
\hline Difference; $p$ & $<0.0001$ & $<0.0001$ & $<0.0001$ \\
\hline Correlation; $r(p)$ & $0.19(0.17)$ & $0.82(<0.001)$ & $0.70(<0.001)$ \\
\hline $\begin{array}{l}\text { Cord/maternal ratio } \\
\text { (mean, range) }\end{array}$ & $\begin{array}{l}0.72 \\
(0.14-2.33)\end{array}$ & $\begin{array}{l}0.34 \\
(0.07-1.51)\end{array}$ & $\begin{array}{l}1.23 \\
(0.72-1.76)\end{array}$ \\
\hline
\end{tabular}

* Mean values were derived after logarithmic transformation of all variables. Analyses of differences between cord and maternal samples used the paired $t$ test on log transformed data. Mean values for cord:maternal ratios for paired sera are shown.

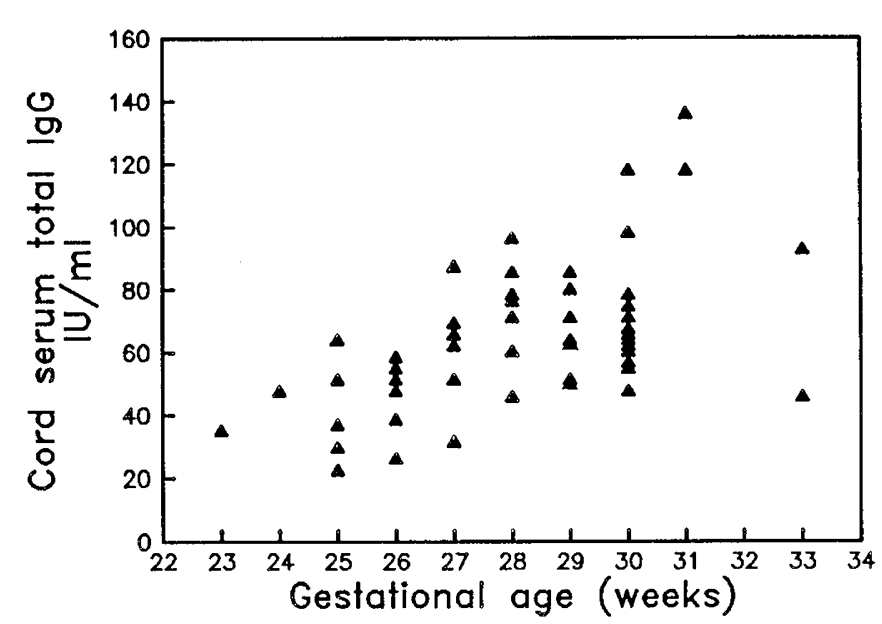

Fig. 1. Total $\mathrm{IgG}$ concentrations $(\mathrm{IU} / \mathrm{mL})$ in cord sera at different gestational ages.

activity was much lower in cord serum than in paired maternal serum (cord-maternal ratio 0.21 ) (Table 3).

The mean heat stable opsonic activity as a proportion of total opsonic activity was 0.64 and 0.34 for cord and maternal sera, respectively. Total and heat stable opsonic activity in cord samples correlated significantly with values for maternal samples $(r$ $=0.58, p<0.01 ; r=0.48, p=0.03$, respectively). A significant correlation also was present for heat labile opsonic activity.

Specific heat-stable opsonic activity and antibody avidity. Heatstable opsonic activity for the pooled E.coli antigens per relative unit of IgG E.coli antibody (specific heat stable opsonic activity) was higher in cord sera than in paired maternal samples (cordmaternal ratio 2.03) with a significant correlation between paired cord and maternal values $(r=0.71 ; p<0.001)$ (Table 4). Specific $\mathrm{IgG}$ antibody avidity was considerably greater in cord serum (cord-maternal ratio 3.42). There was a close correlation between specific heat stable opsonic activity and specific $\mathrm{IgG}$ antibody avidity for cord sera $(r=0.96 ; p<0.001)$ and maternal sera $(r$ $=0.94 ; p<0.001$ ) (Fig. 3).

\section{DISCUSSION}

Little is known with respect to the functional capacity of transplacentally acquired antibody in preterm neonates. As part of a longitudinal study of specific and functional antibody in very low birthweight infants, Cates et al. (16) examined the opsonic capacity of sera from 39 preterm neonates for a coagulase-negative Staphylococcus. They found the mean level of IgGdependent opsonic activity in the newborn period to be significantly lower than that for paired maternal serum samples. There
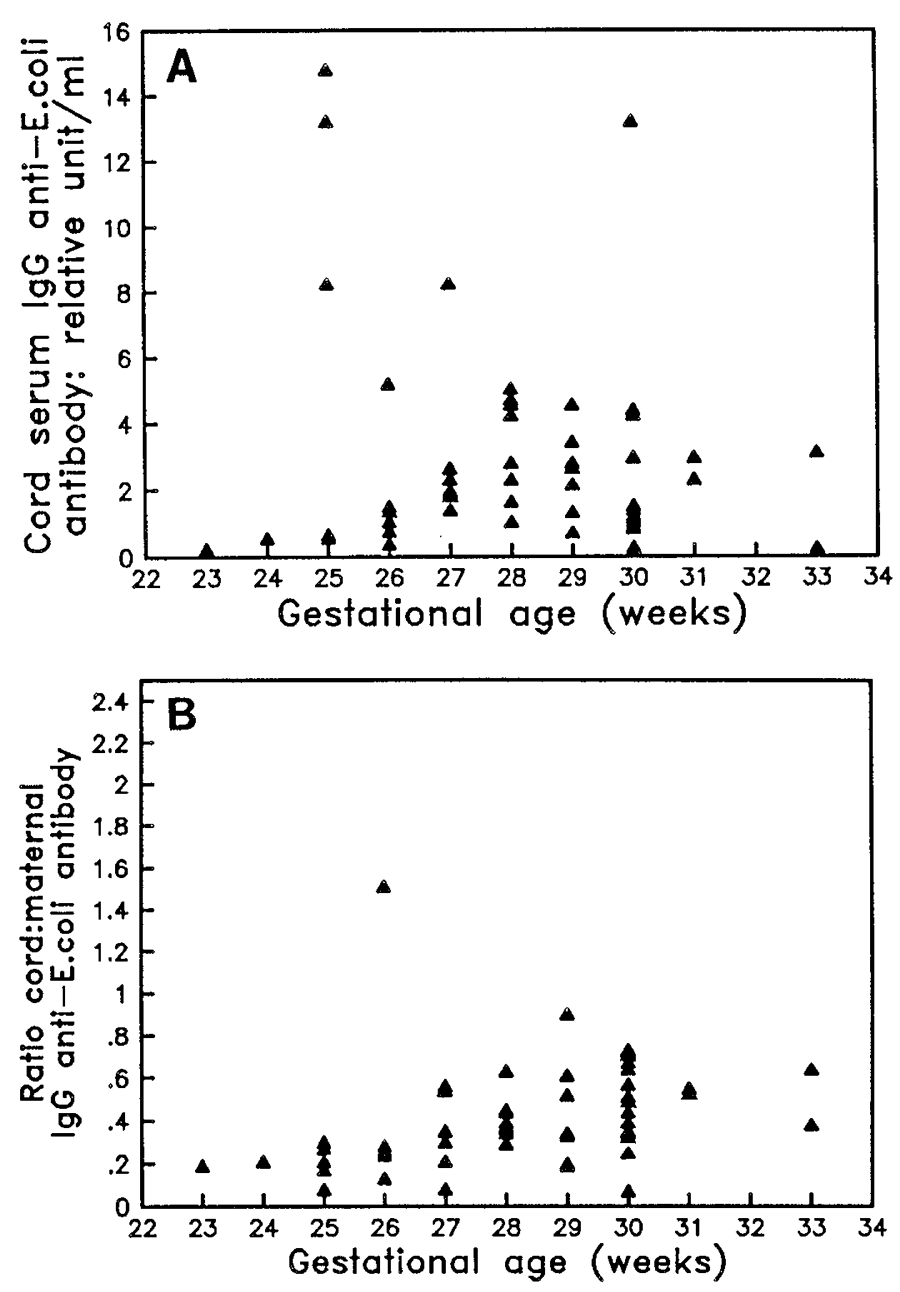

Fig. 2. $A$, $\mathrm{IgG}$ anti-E.coli antibody concentrations (relative $\mathrm{U} / \mathrm{mL}$ ) in cord sera at different gestational ages. $B$, ratio of cord: maternal $\mathrm{gGG}$ antiE.coli antibody concentrations at different gestational ages.

was no correlation between maternal and newborn opsonic activity for this organism. Fleer et al. (15) described similar findings and suggested that functional antibody transfer across the placenta may differ from quantitative total antibody transfer. It is possible that antibody avidity may be one of the components of antibody function that accounts for these observed differences.

The study reported here was performed to determine the avidity of IgG antibody for pooled E.coli antigens in cord blood from preterm neonates (mean gestational age $28 \mathrm{wk}$ ) in compar- 
Table 2. Mean total IgG concentrations, IgG anti-E. coli antibody concentrations and IgG anti-E. coli avidity indices in paired cord and maternal sera $(n=20)$

\begin{tabular}{|c|c|c|c|}
\hline & $\begin{array}{l}\text { Total IgG } \\
\text { (IU/mL) }\end{array}$ & $\begin{array}{l}\text { IgG anti-E. coli antibody } \\
\text { (relative units } / \mathrm{mL} \text { ) }\end{array}$ & $\begin{array}{l}\text { IgG antibody avidity index } \\
\left(\mathrm{M} \mathrm{NH}_{4} \mathrm{SCN}\right)\end{array}$ \\
\hline $\begin{array}{l}\text { Cord serum } \\
\text { (mean, range) }\end{array}$ & $\begin{array}{l}68.0 \\
(46.1-135.6)\end{array}$ & $\begin{array}{l}2.44 \\
(0.72-82.5)\end{array}$ & $\begin{array}{l}2.94 \\
(2.48-3.86)\end{array}$ \\
\hline $\begin{array}{r}\text { Maternal serum } \\
\text { (mean, range) }\end{array}$ & $\begin{array}{l}76.7 \\
(49.9-192.5)\end{array}$ & $\begin{array}{l}5.81 \\
(1.72-14.73)\end{array}$ & $\begin{array}{l}2.07 \\
(1.55-2.92)\end{array}$ \\
\hline Difference; $p$ & 0.25 & $<0.001$ & $<0.001$ \\
\hline Correlation; $r(p)$ & $0.04(0.86)$ & $0.74(<0.001)$ & $0.75(<0.001)$ \\
\hline $\begin{array}{l}\text { Cord/maternal ratio } \\
\text { (mean, range) }\end{array}$ & $\begin{array}{l}0.89 \\
(0.24-1.97)\end{array}$ & $\begin{array}{l}0.41 \\
(0.19-0.90)\end{array}$ & $\begin{array}{l}1.43 \\
(1.20-1.67)\end{array}$ \\
\hline
\end{tabular}

Table 3. Mean opsonic activity of paired cord and maternal sera for pooled E. coli antigens measured by $\operatorname{NIMM}(n=20)^{*}$

\begin{tabular}{|c|c|c|c|}
\hline & \multicolumn{3}{|c|}{$\begin{array}{l}\text { Opsonic activity for pooled } E \text {. coli antigens } \\
\text { (\% untreated pooled normal adult serum) }\end{array}$} \\
\hline & Total $(\%)$ & Heat stable $(\%)$ & Heat labile (\%) \\
\hline $\begin{array}{l}\text { Cord serum } \\
\quad \text { (mean, range) }\end{array}$ & $\begin{array}{l}48.9 \\
(34.1-111.1)\end{array}$ & $\begin{array}{l}31.2 \\
(23.1-43.0)\end{array}$ & $\begin{array}{l}15.0 \\
(4.0-79.0)\end{array}$ \\
\hline $\begin{array}{l}\text { Maternal serum } \\
\text { (mean, range) }\end{array}$ & $\begin{array}{l}109.9 \\
(75.2-194.4)\end{array}$ & $\begin{array}{l}37.0 \\
(27.1-56.3)\end{array}$ & $\begin{array}{l}70.8 \\
(42.1-154.5)\end{array}$ \\
\hline Difference; $p$ & $<0.001$ & $<0.001$ & $<0.001$ \\
\hline Correlation; $r(p)$ & $0.58(<0.01)$ & $0.48(0.03)$ & $0.52(0.02)$ \\
\hline $\begin{array}{l}\text { Cord/maternal ratio } \\
\text { (mean, range) }\end{array}$ & $\begin{array}{l}0.44 \\
(0.26-1.06)\end{array}$ & $\begin{array}{l}0.84 \\
(0.58-1.19)\end{array}$ & $\begin{array}{l}0.21 \\
(0.08-1.22)\end{array}$ \\
\hline
\end{tabular}

* Heat stable: opsonic activity after heating at $56^{\circ} \mathrm{C}$ for $30 \mathrm{~min}$; heat labile: total opsonic activity-heat stable opsonic activity.

Table 4. Specific IgG antibody avidity and specific heat stable opsonic activity for pooled $E$. coli antigens in paired cord and maternal sera $(n=20)^{*}$

\begin{tabular}{lllc}
\hline & \multicolumn{4}{c}{$\begin{array}{c}\text { Specific IgG } \\
\text { antibody avidity }\end{array}$} & $\begin{array}{c}\text { Specific heat stable } \\
\text { opsonic activity }\end{array}$ & $\begin{array}{c}\text { Correlation } \\
r(p)\end{array}$ \\
\hline $\begin{array}{c}\text { Cord serum } \\
\text { (mean, range) }\end{array}$ & $\begin{array}{l}1.22 \\
(0.41-3.49)\end{array}$ & $\begin{array}{l}12.94 \\
(4.14-38.90)\end{array}$ & $0.96(<0.001)$ \\
$\begin{array}{c}\text { Maternal serum } \\
\text { (mean, range) }\end{array}$ & $\begin{array}{l}0.35 \\
(0.14-0.99)\end{array}$ & $\begin{array}{l}6.36 \\
(2.51-18.17)\end{array}$ & $0.94(<0.001)$ \\
& & & \\
Difference; $p$ & $<0.001$ & $<0.001$ & \\
Correlation; $r(p)$ & $0.72(<0.001)$ & $0.71(<0.001)$ & \\
$\begin{array}{c}\text { Cord/maternal ratio } \\
\text { (mean, range) }\end{array}$ & $\begin{array}{l}3.42 \\
(1.48-7.54)\end{array}$ & $\begin{array}{l}2.03 \\
(1.01-5.42)\end{array}$ & $0.92(<0.001)$ \\
\hline
\end{tabular}

* Specific IgG antibody avidity: IgG antibody avidity index $(\mathrm{M}$ $\mathrm{NH}_{4} \mathrm{SCN}$ )/IgG anti-E. coli antibody (relative units/mL). Specific heat stable opsonic activity: heat stable opsonic activity (\% untreated pooled adult serum)/lgG anti- $E$. coli antibody (relative units $/ \mathrm{mL}$ ).

ison with the avidity of maternal IgG antibody for the same antigen. The mean relative avidity index for the 52 cord sera tested was $2.45 \mathrm{M}$; that for paired maternal sera collected within $48 \mathrm{~h}$ of birth was significantly lower $(1.99 \mathrm{M} ; p<0.0001)$. There was a significant correlation of the avidity values for $\operatorname{IgG}$ antibody to the E.coli antigens between paired cord and maternal sera $(r$ $=0.70 ; p<0.001$ ), but there was no correlation of the avidity of cord IgG anti-E.coli antibody with gestational age.
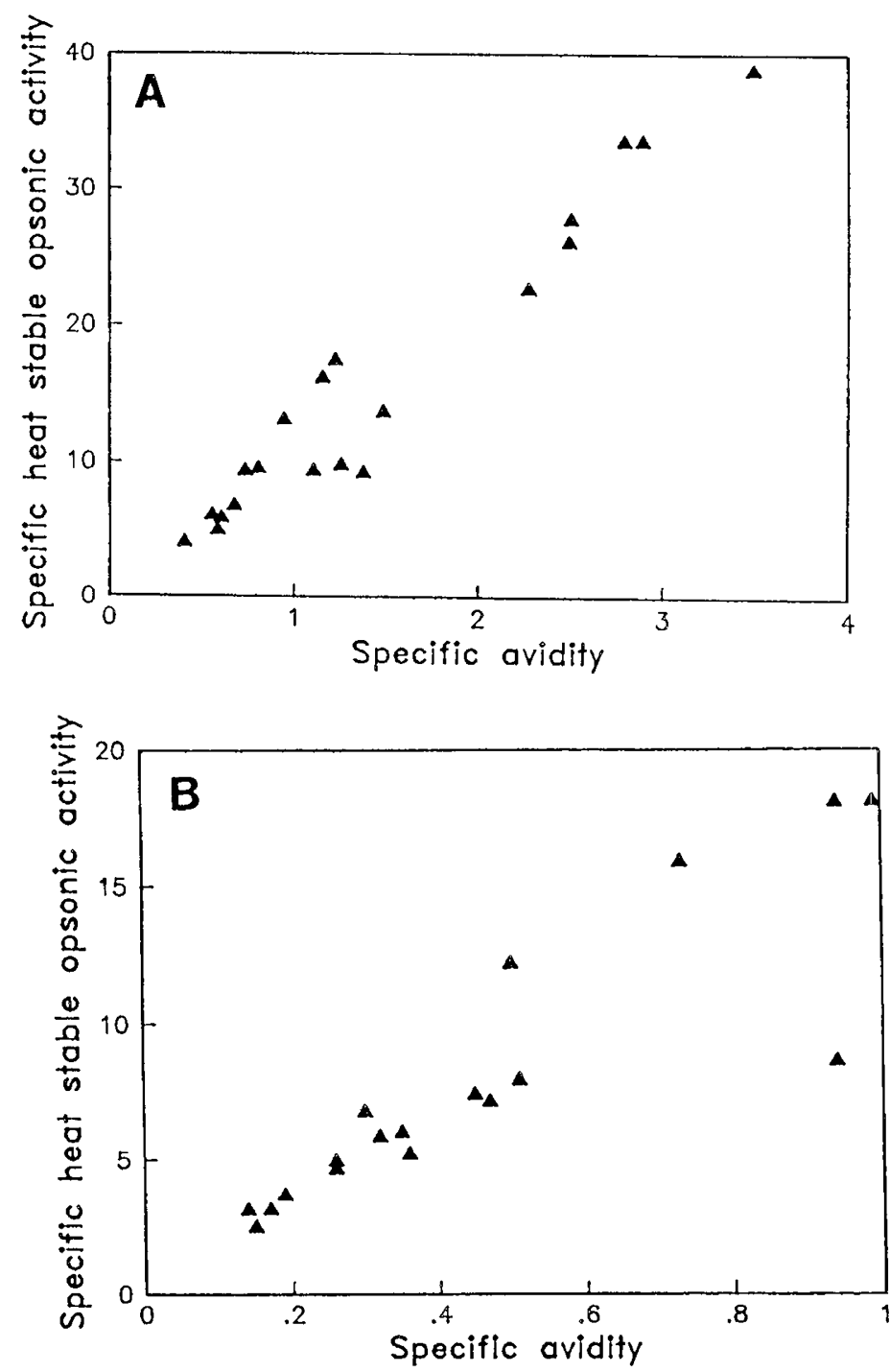

Fig. 3. $A$, specific heat stable opsonic activity (heat stable opsonic activity/relative unit of $\mathrm{IgG}$ anti-E.coli antibody) and specific avidity (M $\mathrm{NH}_{4} \mathrm{SCN} /$ relative unit of $\mathrm{IgG}$ anti-E.coli antibody) in cord sera. $B$, specific heat stable opsonic activity (heat stable opsonic activity/relative unit of IgG anti-E.coli antibody) and specific avidity (M NH4SCN/ relative unit of $\operatorname{IgG}$ anti-E.coli antibody) in maternal sera. 
It is known that there is a close correlation between gestational age and cord or neonatal serum IgG concentrations. Others have demonstrated an increase in cord blood $\operatorname{IgG}$ concentrations to values often considerably greater than those for paired maternal serum samples with increasing length of gestation $(2,11,12,33)$, suggesting active transplacental IgG transport. It has been shown also that the concentrations of IgG antibody to specific antigens frequently are greater in cord blood samples than in paired maternal sera later in gestation, although the ratio of cord to maternal antibody concentrations may differ for different antigens $(7,13,14)$.

Similar results were shown for the very premature infants enrolled in the study reported here. Cord blood total IgG concentrations correlated with gestational age (partial correlation coefficient, controlled for maternal IgG concentrations, $0.55 ; p$ $<0.001$ ) but were poorly correlated with maternal IgG concentrations, even when controlled for the effect of varying gestational age by use of partial regression analysis $(r=0.20 ; p=0.08)$. These results suggest that gestational age is a more important determinant of transplacental $\mathrm{IgG}$ transport in prematurity than is total maternal IgG concentration.

However, IgG antibody concentrations in cord sera to E.coli antigens correlated weakly with gestational age (partial correlation coefficient, controlled for maternal IgG anti-E.coli antibody concentrations, $0.23 ; p=0.06$ ). Thus, it appears that factors other than total IgG transport determine maternal to fetal transfer of IgG anti-E.coli antibody in prematurity. This is supported by the finding that the mean cord:maternal IgG anti-E.coli antibody ratio of 0.34 was significantly lower than the mean cord: maternal total $\mathrm{IgG}$ ratio of 0.72 . Maternal $\mathrm{IgG}$ anti-E.coli antibody concentrations are important with respect to specific antibody transfer to the neonate as shown by the close correlation of cord and maternal IgG E.coli antibody concentrations when controlled for the effect of gestational age (partial correlation coefficient $0.89 ; p<0.001$ ). When cord IgG anti-E.coli antibody concentrations were expressed as a proportion of maternal IgG anti-E.coli antibody concentrations, a relatively weak but significant correlation with gestational age was seen $(r=0.42 ; p<$ 0.001 ). For maternofetal transfer of IgG anti-E.coli antibody, the maternal IgG anti-E.coli concentration is a more important factor than gestational age in determining fetal $\mathrm{IgG}$ anti-E.coli concentrations.

The relatively low cord:maternal ratio of $\mathrm{IgG}$ anti-E.coli antibody contrasts markedly with the finding of a significantly higher avidity of IgG anti-E.coli antibody in cord sera in comparison with paired maternal sera in this study. This finding suggests that there is selective transport of high avidity $\operatorname{IgG}$ antiE.coli antibody from maternal serum. Transport of high avidity antibody could be a compensatory mechanism for the lower total concentration of antibody, providing the neonate with antibody of greater functional activity. The antigen preparation used for the assays of antibody avidity consisted of a mixture of surface and internal E.coli antigens, the latter probably being of limited importance in host-recognition and clearance in vivo. To investigate the significance of the findings with respect to antibody avidity further, assays of opsonic activity of paired cord and maternal sera were performed, using heat killed organisms of the same pooled E.coli strains as for the antibody and avidity assays. The neutrophil iodination assay chosen uses neutrophil oxidative metabolic activation as an indirect measure of opsonisation and correlates closely with other measures of opsonisation and microbicidal activity $(30,31)$. Untreated serum represents the total opsonic capacity of serum (antibody, complement, and other factors) to promote attachment, ingestion, degranulation, and metabolic activation of polymorphonuclear leucocytes in the presence of organisms. Prior heating of the serum to $56^{\circ} \mathrm{C}$ was used to provide an estimate of the proportion of the total serum opsonic activity related to complement activity.

The results of these assays showed that total opsonic activity in cord serum samples for the pooled E.coli antigens was only
$44 \%$ of that of paired maternal serum samples, with the majority of the difference between cord and maternal serum samples being due to deficiencies of heat labile factors (largely complement) as expected $(3,34)$. However, at the serum concentrations used in the opsonic assays $(2.8 \%)$, chosen to give optimal enhancement of iodination responses $(30,31,35)$, heat stable opsonic activity in the cord serum samples from these very premature neonates was $84 \%$ of that of the maternal samples. Heat stabile opsonic activity accounted for $64 \%$ of the total opsonic activity of cord serum, but only one-third of the total activity of maternal serum. When corrected for IgG anti-E.coli antibody concentrations, which were markedly lower in cord sera than in maternal sera, the heat stable opsonic activity per unit of IgG anti-E.coli antibody was 2 -fold greater in cord sera than matenal sera. This finding is in contrast to the results of the phagocytosis assays used by Marodi et al. (36), perhaps because that study used a single E.coli strain (O54), which may colonize less frequently and to which serum antibody may not have been present in some of the test samples.

Antibody avidity has been suggested by others to be important for opsonising activity $(37,38)$. In our study, IgG anti-E.coli avidity expressed as a measure of antigen-binding capacity of each unit of IgG antibody (specific IgG antibody avidity) correlated closely with heat stable opsonic activity for the pooled E.coli antigens both for cord and maternal sera. Therefore it is likely that the higher avidity of IgG anti-E.coli antibody in cord sera is responsible for the improved heat stable opsonising capacity of cord sera ( $84 \%$ of maternal values), even though $\mathrm{IgG}$ anti-E.coli antibody concentrations in cord sera were only $41 \%$ of maternal values for the 20 cord-maternal pairs evaluated. This improvement in heat-stable opsonizing capacity of cord serum may in reality be even greater than that demonstrated in this study, as maternal serum results for heat stable opsonic activity will also in part be due to IgM antibody, which was present in cord serum in much lower concentrations.

Opsonic activity in serum has been shown to correlate with protection in animal models $(39,40)$, and IgG antibody may provide greater protection than IgM antibody (35). Therefore, the selective transplacental transport of $\mathrm{IgG}$ antibody of high avidity may have functional importance in improving the protective capacity of the low concentrations of neonatal antibody present. However, the mechanism of selective transport of high avidity IgG antibody is unclear. It seems unlikely that the affinity of antibody for specific antigen will allow preferential Fc-mediated transport per se, but a possible explanation is that antibody of differing IgG subclasses may have different avidity characteristics for the same antigen, as suggested by Persson et al. (38) and Devey et al. (41). It will be of interest to determine the relative subclass distribution of $\operatorname{IgG}$ anti-E.coli antibody in maternal and cord serum in premature neonates of differing gestational ages, and then measure the relative avidity of IgG subclass specific antibody, perhaps by using negative selection procedures to isolate the subclass of interest (38).

Our findings suggest that selective transplacental transfer of high avidity $\mathrm{IgG}$ antibody to $E$.coli antigens occurs during pregnancy. This selective transfer may afford a mechanism for the provision of greater protection from infection due to E.coli in the neonatal period, and may be of relevance with respect to neonatal protection from infection by other organisms.

Acknowledgments. The authors thank Drs. L. W. Doyle, V. Y. $\mathrm{Yu}$, and $\mathrm{K}$. J. Healey for assistance in this study.

\section{REFERENCES}

1. Conway SP, Dear PRF, Smith 1985 Immunoglobulin profile of the preterm baby. Arch Dis Child 60:208-212

2. Toivanen $\mathrm{P}$, Mantyjarvi R, Hirvonen $\mathrm{T} 1968$ Maternal antibodies in human foetal sera at different stages of gestation. Immunology 15:395-403

3. Stiehm ER 1986 Intravenous immunoglobulins in neonates and infants: an overview. Pediatr Infect Dis 5:217-219 
4. Gitlin D, Biasucci A 1969 Development of IgG, IgA, IgM, B1C/B1A, C1 esterase inhibitor, ceruloplasmin, transferrin, hemopexin, haptoglobin, fibrinogen, plasminogen, alphal-antitrypsin, orosomucoid, B-lipoprotein,A2macroglobulin and prealbumin in the human conceptus. J Clin Invest 48:1433-1446

5. Morell A, Sidiropoulos D, Herrmann U, Christensen KK, Christensen P, Prellner K, Fey H, Skvaril F 1986 IgG subclasses and antibodies to group B streptococci, pneumococci and tetanus toxoid in preterm neonates after intravenous infusion of immunoglobulin to the mothers. Pediatr Res 20:933936

6. Morell A, Sidiropoulos D, Herrmann U, Christensen KK, Christensen P, Prellner K, Skvaril F 1986 IgG subclasses and antibodies to group B streptococci in preterm neonates after intravenous infusion of immunoglobulin to the mothers. Pediatr Infect Dis 5:s195-s197

7. Boyer KM, Papierniak CK, Gadzala CA, Parvin JD, Gotoff SP 1984 Transplacental passage of IgG antibody to group B streptococus serotype la. J Pediatr 104:618-620

8. Chudwin DS, Wara DW, Schiffman G, Artrip SG, Ammann AJ 1985 Maternal-fetal transfer of pneumococcal capsular polysaccharide antibodies. Arch Dis Child 139:378-380

9. Pitcher-Wilmott RW, Hindocha P, Wood CBS 1980 The placental transfer of $\mathrm{IgG}$ subclasses in human pregnancy. Clin Exp Immunol 41:303-308

10. Oxelius VA, Svenningsen NW $1984 \mathrm{IgG}$ subclass concentrations in preterm neonates. Acta Paediatr Scand 73:626-630

11. Morell A, Skvaril F, van Loghem E, Kleemola M 1971 Human IgG subclasses in maternal and fetal serum. Vox Sang 21:481-492

12. Kohler PF, Farr RS 1966 Elevation of cord over maternal IgG immunoglobulin: evidence for an active placental IgG transport. Nature 210:1070-1071

13. Einhorn MS, Granoff DM, Nahm MH, Quinn A, Shackelford PG 1987 Concentrations of antibodies in paired maternal and infant sera: Relationship to IgG subclass. J Pediatr 111:783-788

14. Sato H, Albrecht P, Reynolds DW, Stagno S, Ennis FA 1979 Transfer of measles, mumps and rubella antibodies from mother to infant. Am J Dis Child 133:1240-1243

15. Fleer A, Gerards LJ, Aerts P, Westerdaal NAC, Senders RC, van Dijk H, Verhoef J 1985 Opsonic defense to Staphylococcus epidermidis in the premature neonate. J Infect Dis 152:930-937

16. Cates KL, Goetz C, Rosenberg N, Pantschenko A, Rowe JC, Ballow M 1988 Longitudinal development of specific and functional antibody in very low birth weight premature infants. Pediatr Res 23:14-22

17. Steward MW, Lew AM 1985 The importance of antibody affinity in the performance of immunoassays for antibody. J Immunol Methods 78:173190

18. Steward MW, Steensgard J 1983 The biological significance of antibody affinity. In: Antibody Affinity: Thermodynamic Aspects and Biological Significance. CRC Press, Boca Raton, FL. pp 145-153

19. Pullen GR, Fitzgerald MG, Hosking CS 1986 Antibody avidity determination by ELISA using thiocyanate elution. J Immunol Methods 86:83-87

20. Roberton DM, Forrest PJ, Frangoulis E, Jones CL, Mermelstein N 1986 Early induction of secretory immunity in infancy:specific antibody in neonata breast milk. Arch Dis Child 61:489-494

21. Turner KJ, Carter PM, Hosking CS, Finger WK 1980 The Australian reference preparation of human serum immunoglobulins. Aust J Exp Biol Med Sci 58:351-356

22. Turck M, Petersdorf RG, Fournier MR 1962 The epidemiology of non-enteric Escherichia coli infections: prevalence of serological groups. J Clin Invest 41:1760-1765

23. Lidin-Janson G, Hanson LA, Kaijser B, Lincoln K, Lindberg U, Olling S,
Wedel H 1977 Comparison of Escherichia coli from bacteriuric patients with those from feces of healthy school children. J Infect Dis 136:346-353

24. Warburg O, Christian W 1942 Isolation and crystallization of enolase. Biochem Z 310:384-421

25. Young NS, Levin J, Prendergast RA 1972 An invertebrate coagulation system activated by endotoxin: evidence for enzymatic mediation. $J$ Clin Invest 51:1790-1797

26. Vogt RF, Phillips DL, Henderson LO, Whitfield W, Spierto FW 1987 Quantitative differences among various proteins as blocking agents for ELISA microtiter plates. J Immunol Methods 101:43-50

27. Macdonald RA, Hosking CS, Jones CL 1988 The measurement of relative antibody affinity by ELISA using thiocyanate elution. J Immunol Methods 106:191-195

28. Sennhauser FH, Macdonald RA, Roberton DM, Hosking CS 1989 Comparison of concentrations and avidity of specific antibodies to $E$ coli in breast milk and serum. Immunology 66:394-397

29. Roberton DM, Carlsson B, Coffman K, Hahn-Zoric M, Jalil F, Jones C Hanson LA 1988 Avidity of IgA antibody to Escherichia coli polysaccharide and diphtheria toxin in breast milk from Swedish and Pakistani mothers. Scand J Immunol 28:783-789

30. Roberton DM, Dhanjal NK, Levinsky RL, Mowbray JF, Turner MW 1981 Polymorphonuclear neutrophil iodination response as an estimate of defective yeast opsonisation. Clin Exp Immunol 43:208-214

31. Pereira HA, Shelton MH, Hosking CS 1983 Neutrophil iodination micromethod as an index of neutrophil and opsonic function. J Lab Clin Immunol 11:47-52

32. McLaren ML, Lillywhite JE, Au AC 1981 Indirect enzyme immunosorbent assay (ELISA): practical aspects of standardization and quality control. Med Lab Sci 38:245-251

33. Hyvarinen M, Zeltzer P, Oh W, Stiehm ER 1973 Influence of gestational age on serum levels of alpha-1 fetoprotein, IgG globulin and albumin in newborn infants. J Pediatr 82:430-437

34. McCracken GH, Eichenwald HF 1971 Leucocyte function and the development of opsonic and complement activity in the neonate. Am J Dis Child $121: 120-126$

35. Kim KS, Kang JH, Cross AS, Kaufman B, Zollinger W, Sadoff J 1988 Functional activities of monoclonal antibodies to the O side chain of Escherichia coli lipopolysaccharides in vitro and in vivo. J Infect Dis 157:47-53

36. Marodi L, Leijh PCI, Braat A, Daha MR, van Furth R 1985 Opsonic activity of cord blood sera against various species of microorganism. Pediatr Res 19:433-436

37. Ahlstedt S, Holmgren J, Hanson LA 1972 Significance of amount and avidity of $E$. coli $\mathrm{O}$ antibodies for manifestation of their serological and protective properties. Int Arch Allergy 42:826-835

38. Persson MAA, Brown SE, Steward MW, Hammarstrom L, Smith CIE, Howard CR, Wahl M, Rynnel-Dagoo B, Lefranc G, Carbonara AO 1988 IgG subclassassociated affinity differences of specific antibodies in humans. J Immunol 140:3875-3879

39. Bortolussi R, Fischer GW 1986 Opsonic and protective activity of immunoglobulin, modified immunoglobulin and serum against neonatal Escherichia coli $\mathrm{K} 1$ infection. Pediatr Res 20:175-178

40. Kaufman BM, Cross AS, Futrovsky SL, Sidberry HF, Sadoff JC 1986 Monoclonal antibodies reactive with K1-encapsulated Escherichia coli lipopolysaccharide are opsonic and protect mice against lethal challenge. Infect Immun 52:617-619

41. Devey M, Bleasdale KM, French MAH, Harrison G 1985 The IgG4 subclass is associated with a low affinity response to tetanus toxoid in man. Immunology 55:565-567 